\title{
PETROLEUM-COLLECTING AND DISPERSING CHEMICALS FOR CLEANING SEA SURFACE FROM THIN PETROLEUM SLICKS
}

\author{
Ziyafaddin H. Asadov, Ilhama A. Zarbaliyeva, Ravan A. Rahimov", Nargiz V. Salamova, \\ Solmaz K. Eyyubova, Gulnara A. Ahmadova and Aygul Z. Asadova \\ Institute of Petrochemical Processes of Azerbaijan National Academy of Sciences, \\ Hojaly Ave. 30, Az 1025, Baku, Azerbaijan
}

(Received February 5, 2013; revised January 16, 2014)

\begin{abstract}
Monoethylolamide, diethylolamide and triethanolamine ester synthesized by us based on fish oil and their phosphate derivatives being surface-active and ecologically safe possess a high capacity of petroleum collecting and dispersing. When introducing phosphate group, a tendency to replacement of petroleum slick dispersing by its collection (accumulation into a spot) is observed. Efficiency of the chemicals change depends on the type and concentration of ions in the water. Such salts as $\mathrm{NaCl}, \mathrm{KI}, \mathrm{KBr}$, and $\mathrm{MgSO}_{4}$ positively influence petroleum-collecting activity whereas $\mathrm{K}_{2} \mathrm{CO}_{3}$ and $\mathrm{NaHCO}_{3}$ cause petroleum dispersing.
\end{abstract}

KEY WORDS: Oil slicks, Petroleum-collecting, Petroleum-dispersing, Ethylolamides, Ester, Phosphate, Surfactant

\section{INTRODUCTION}

As other water basins of the world, the Caspian Sea has its specific problems among which pollution of the reservoir and related with it the deterioration of ecological situation hereabouts are the most important. The main sources of this sea pollution are petroleum-carrying sea transport and oil fields [1].

Characteristic features of pollution with petroleum and its products are contamination of all components of the environment, their dissipation in large aquatic areas, accumulation in bottom sediments and others. Petroleum slicks worsen water quality and negatively impact oxygen regime by disordering a balanced relation of the upper water layers with atmosphere [2, 3]. Films of petroleum origin reflecting sunlight rays hinder absorption of energy by water necessary for life activity of marine inhabitants. Removal of such slicks is particularly important because more than a hundred fish species habitate in the Caspian Sea, among them $95 \%$ of the world sturgeon population [4].

After the accident at the crude oil platform in the Mexican gulf a realization of safety measures in the Caspian Sea oil fields, one of the largest centers of hydrocarbon raw [5], is very urgent. Among such measures of a great significance are issues of liquidation of consequences of a possible petroleum spill. Spilled petroleum may be mainly removed by mechanical ways [6]. However, a part of this petroleum remains on the water surface as slicks. These slicks can be liquidated only by using certain physico-chemical methods including an application of dispersants [7, 8] and collectors [9].

Dispersing chemicals like mechanical clean-up methods have their own place in fighting oil spills. They are considered as a potential response along with mechanical containment and clean-up of oil slicks off the water surface. They decompose these slicks into tiny emulsions which are later subjected to biochemical destruction under the influence of microorganisms, wind, light, etc. The danger of the petroleum emulsified by dispersants does not exceed that of mechanically dispersed one, provided that their concentrations are equal [10, 11].

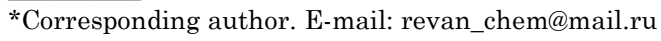


Dispersants efficiency is influenced by various factors [12, 13]. Byford [14] showed that dispersants efficiency changes depending on salinity of water. Fingas et al. [15] carried out swirling flask test on Alberta Sweet Mixed Blend, Norman Wells, Adgo crude oils with Corexit 9527, Enersperse 700 and Citrikleen dispersants in water with salinity between 0 and 100 ppt. All tests were completed with pre-mixed dispersant and oil. Freshwater effectiveness was low for all dispersants and oil combinations. Maximum effectiveness was achieved at 40 to $45 \mathrm{ppt}$ and fell sharply with either a decrease or increase in salinity.

In the past twenty years specialists of the Institute of Petrochemical Processes of National Academy of Azerbaijan have developed a lot of petroleum-dispersing and petroleum-collecting chemicals [16-18]. Petroleum-collecting is an accumulation of slicks into a thickened spot which is later easily removed by mechanical devices. Efficiency of petroleum-collecting and dispersing chemicals is greatly influenced by such factors as ion composition of water, type of petroleum, concentration of ions in water, thickness of petroleum slick and others [19].

This paper describes the results of studies on obtaining new petroleum-collecting and petroleum-dispersing chemicals based on ecologically harmless raw materials as well as researches of impact of various factors on these chemicals efficiency.

\section{EXPERIMENTAL}

\section{Materials}

Fish oil was purchased from "Aksuvital" (Turkey). Monoethanolamine (MEA), diethanolamine (DEA) and triethanolamine (TEA) were received from "Kazanorgsintez" Joint Stock Company (Russia). Orthophosphoric acid (85\% wt solution) was product of Moscow's "ComponentReactant" Joint Stock Company (Russia). All these reactants were used without any further purification.

${ }^{1} \mathrm{H}$ NMR and ${ }^{13} \mathrm{C}$ NMR spectra were recorded on Bruker TOP SPIN $300.13 \mathrm{MHz}$ and 75.46 $\mathrm{MHz}$ spectrometer with chemical shift values $(\delta)$ in ppm downfield from TMS using $\left(\mathrm{CD}_{3}\right)_{2} \mathrm{CO}$ as solvents. IR-spectra were recorded by spectrometer FT-IR, Spectrum BX (Perkin Elmer) using $\mathrm{KBr}$ disks.

Surface activity was studied by stalagmometric method at the water-kerosene interface $\left(21^{\circ} \mathrm{C}\right)$.

\section{Synthesis of alkylolamides and TEA ester from fish oil}

Fish oil $(0.03 \mathrm{~mol})$ and ethanolamine $(0.09 \mathrm{~mol})$ were weighed into a $250 \mathrm{~mL}$ round bottomed flask and reacted with agitation at $140-150{ }^{\circ} \mathrm{C}$ for $10-12 \mathrm{~h}$. The reaction flask was equipped with a mechanical stirrer, thermometer and condenser. The reaction product was dissolved in water and placed in a separator funnel. The mixture was washed with $20 \mathrm{~mL}$ of $5 \%$ aqueous hydrochloric acid to remove excess amine and glycerol. The wax layer was separated, washed with two $100 \mathrm{~mL}$ portions of water, boiled with $0.5 \mathrm{~g}$ of decolorizing charcoal to remove the yellow color, and filtered. The monoethylolamide (diethylolamide or TEA ester) was dried over potassium carbonate and the water was rotary-evaporated. The monoethylolamide and TEA ester yields equaled $90-92 \%$.

During synthesis of diethylolamide, the reaction product was dissolved in acetone, and placed in the condenser at minus $25-28{ }^{\circ} \mathrm{C}$ temperature. The wax phase separated with filtered and dried. The diethylolamides were recrystallized from acetone. Diethylolamide yields were equal to $87-89 \%$. 
Synthesis of phosphate derivatives from ethylolamides and TEA ester of fish oil

The ethylolamides and $\mathrm{H}_{3} \mathrm{PO}_{4}$ were placed in the flask and heated to $55-60{ }^{\circ} \mathrm{C}$ temperature. The ethylolamides were then reacted with $\mathrm{H}_{3} \mathrm{PO}_{4}$ at molar ratio of $1: 1$. Water bath was used to maintain a constant temperature. The reaction mixture was stirred continuously for a predetermined reaction period. The progress of reaction was monitored by analyzing the amount of unreacted $\mathrm{H}_{3} \mathrm{PO}_{4}$ in the reaction mixture by a titrimetric method. For purification, the product was dissolved in a mixture of ethanol.

\section{Methods of studying petroleum-collecting and dispersing capacities of chemicals}

A study of influence of inorganic salts on petroleum-collecting and dispersing properties of the obtained diethylolamide and its phosphate has been performed according to the following procedure. Into Petri dish $40 \mathrm{~mL}$ of water were placed and onto it $1 \mathrm{~mL}$ of petroleum was added. The formed petroleum slick has a thickness $\sim 0.165 \mathrm{~mm}$. After formation of the slick a necessary amount (usually $0.02 \mathrm{~g}$ ) of a tested chemical itself or of its $5.0 \%$ wt. aqueous solution was added from a peripheral point. Directly after initial accumulation of crude oil into a spot its surface area $\left(\mathrm{S}_{0}\right)$ was measured. Knowing the initial area of the slick surface $\left(\mathrm{S}_{\mathrm{in}}\right)$, the initial coefficient of petroleum collection $\left(\mathrm{K}_{\mathrm{in}}=\mathrm{S}_{\mathrm{in}} / \mathrm{S}_{0}\right)$ was calculated. Further, in certain periods of time $-\tau$ measurements of the spot surface area were made up to complete spill of the petroleum and current values of petroleum collection $(\mathrm{K})$ were calculated.

In the case of petroleum dispersing, duration of the chemicals action was determined according to observations. The degree (or percentage) of the surface cleaning was also computed as the ratio of clean water surface and that of the initial slicks surface.

\section{Crude oils and water}

Four types of crude oil were used in the tests: (1) Ramany oil field (near Baku) - density $\rho^{20}=$ $0.862 \mathrm{~g} / \mathrm{mL}$, kinematic viscosity $v^{20}=16.8 \mathrm{cSt}$., (2) Neft Dashlary oil field (in the Caspian Sea) $\rho^{20}=0.887 \mathrm{~g} / \mathrm{mL}, v^{20}=15.7$ cSt., (3) Gunashly oil field (in the Caspian sea) $-\rho^{20}=0.861 \mathrm{~g} / \mathrm{mL}$, $v^{20}=15.7$ cSt., and (4) May 28 oil field (in the Caspian sea) $-\rho^{20}=0.856 \mathrm{~g} / \mathrm{mL}, v^{20}=9.7 \mathrm{cSt}$.

In the experiments 4 kinds of water were taken: (i) distilled water, (ii) fresh water, (iii) The Caspian Sea water having the following physico-chemical characteristics and composition: $\rho^{20}=$ $1.0098 \mathrm{~g} / \mathrm{mL}, \mathrm{pH}=7.7$; contents of ions and other species $(\mathrm{mg} / \mathrm{L}): \mathrm{Na}^{+}-2650 ; \mathrm{K}^{+}-90 ; \mathrm{Ca}^{2+}$ $250 ; \mathrm{Mg}^{2+}-900 ; \mathrm{NH}_{4}{ }^{+}-0.15 ; \mathrm{Cl}^{-}-500 ; \mathrm{SO}_{4}{ }^{2-}-2800 ; \mathrm{NO}_{3}{ }^{-}-0.1 ; \mathrm{PO}_{4}{ }^{3-}-0.35 ; \mathrm{NO}_{2}{ }^{-}-0.007 ;$ $\mathrm{SiO}_{2}-0.5$; petroleum products - $0.005 \%$; dissolved oxygen- $8 \mathrm{mg} / \mathrm{L}$, total hardness - $69.0 \mathrm{mg}-$ eq/L, and (iv) the layer water from Surakhany oil field (near Baku) of such physico-chemical characteristics: $\rho^{20}=1.040 \mathrm{~g} / \mathrm{mL}, \mathrm{pH}=7.1$; chemical composition $(\mathrm{mg} / \mathrm{L}): \mathrm{Ca}^{2+}-2280 ; \mathrm{Mg}^{2+}$ 690; $\mathrm{SO}_{4}{ }^{2-}-2640 ; \mathrm{Cl}^{-}-49900$; iodine (bound) - 1860; naphthenic acids - 6.6; petroleum - 28.0; dissolved oxygen - 6.0; suspended substances - 360.0; dry residue - 81.26 ; alkalinity - $16.0 \mathrm{mg}$ eq/L, total hardness - $60.0 \mathrm{mg}-\mathrm{eq} / \mathrm{L}$.

\section{RESULTS AND DISCUSSION}

\section{Synthesis of ethylolamides}

The fish oil was reacted with MEA, DEA and TEA at molar ratio of 1:3 (Scheme 1 and 2). Glycerol was being produced as the by-product of the reaction: 


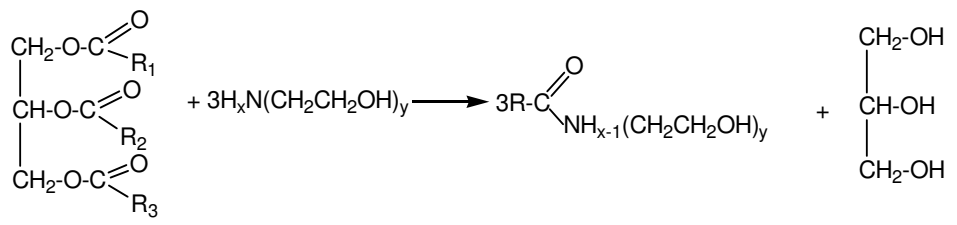

Scheme 1. Reaction scheme of the synthesis of mono- and diethylolamide, where $\mathrm{x}=2$ or $1 ; \mathrm{y}=$ 1 or $2 ; \mathrm{R}_{1}, \mathrm{R}_{2}, \mathrm{R}_{3}$ are the alkyl chains.

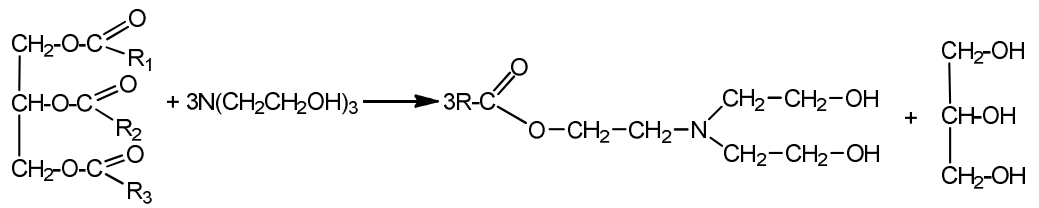

Scheme 2. Reaction scheme of the synthesis of TEA ester of fish oil; where $R_{1}, R_{2}, R_{3}$ are the alkyl chains.

The general scheme of the conducted modification reaction is as following:

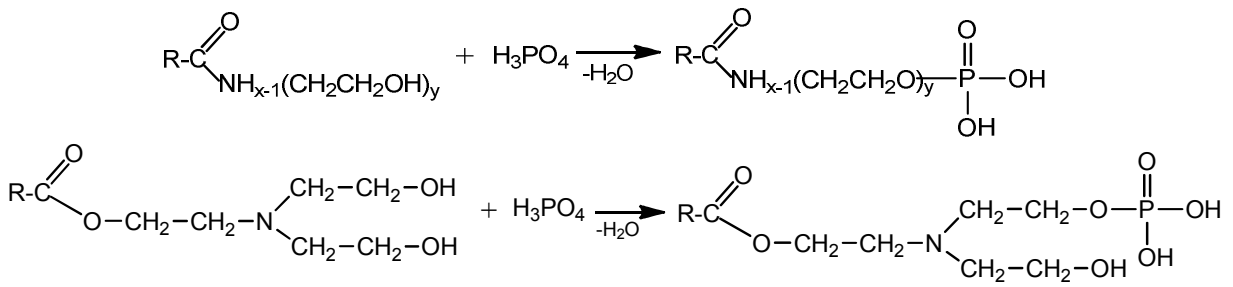

Scheme 3. Reaction scheme of the synthesis of ethylolamide and TEA ester phosphates.

The reaction of phosphation is accompanied by heat liberation, increasing of viscosity and color darkening.

Fish oil monoethylolamide phosphate (FMEAPh) is a dark-brown, paraffin-like substance, soluble in $\mathrm{CCl}_{4}$, acetone, isopropyl alcohol, benzene, kerosene and partially soluble in water and isooctane. The specific electrical conductivity of its $0.5 \%$ wt. aqueous solution is 0.00278 $\mathrm{ohm}^{-1} \cdot \mathrm{m}^{-1}$. The acid number is $99.7 \mathrm{mg} \mathrm{KOH} / \mathrm{g}$. IR cm ${ }^{-1}: 3290 v(\mathrm{~N}-\mathrm{H}), 2921$ and $2851 v(\mathrm{C}-\mathrm{H})$, $1641 v(\mathrm{~N}-\mathrm{C}=\mathrm{O}), 1550 \delta(\mathrm{N}-\mathrm{H}), 1456$ and $1377 \delta(\mathrm{C}-\mathrm{H}), 1119 v(\mathrm{C}-\mathrm{N}), 1050 v(\mathrm{P}-\mathrm{O}), 721\left(\mathrm{CH}_{2}\right)_{\mathrm{x}}$. ${ }^{1} \mathrm{H}-\mathrm{NMR}\left(300.13 \mathrm{MHz}\right.$, asetone-d $\left.{ }^{6}\right), \delta(\mathrm{ppm}): 0.7-1.7\left(\mathrm{CH}_{3}\right)$ and $\left(\mathrm{CH}_{2}\right), 2.0\left(\mathrm{CH}_{2} \mathrm{O}\right), 2.7$ $\left(\mathrm{NCH}_{2}\right), 3.5(\mathrm{CH}=\mathrm{CH}), 5.3(\mathrm{C}-\mathrm{OH}), 7.5(\mathrm{P}-\mathrm{OH}) .{ }^{13} \mathrm{C}-\left\{{ }^{1} \mathrm{H}\right\}$ NMR $\left(75.46 \mathrm{MHz}\right.$, acetone-d $\left.\mathrm{d}^{6}\right), \delta$ (ppm): 16.0-44.0 (alkyl chain), $63.0\left(\mathbf{C H}_{2} \mathrm{O}\right), 129.0-132.5\left(\mathbf{C H}_{2}-\mathrm{NH}\right), 177.0-179.0 \mathbf{C}(\mathrm{O}) \mathrm{N}$

Fish oil diethylolamide phosphate (FDEAPh) is a brown-red relatively flowing liquid, soluble in water acetone, $\mathrm{CCl}_{4}$, benzene and partially soluble in isooctane, kerosene and insoluble in isopropyl alcohol. The specific electrical conductivity of $0.5 \%$ wt. aqueous solution is $0.0075 \mathrm{ohm}^{-1} \cdot \mathrm{m}^{-1}$. The acid number is $123.5 \mathrm{mg} \mathrm{KOH} / \mathrm{g}$. IR $\mathrm{cm}^{-1}: 3010 v(\mathrm{O}-\mathrm{H}), 2922$ and $2852 v(\mathrm{C}-\mathrm{H}), 1710 v(\mathrm{O}-\mathrm{C}=\mathrm{O}), 1452 \delta(\mathrm{C}-\mathrm{H}), 1113 v(\mathrm{C}-\mathrm{N}), 1036 v(\mathrm{P}-\mathrm{O}), 720\left(\mathrm{CH}_{2}\right)_{\mathrm{x}}$.

Fish oil TEA ester phosphate (FTEAPh) is a brown viscous liquid, soluble in $\mathrm{CCl}_{4}$ and water, isooctane, giving an opaque solution in isopropanol and kerosene. The specific electrical conductivity of $0.5 \%$ wt. aqueous solution is $0.00195 \mathrm{ohm}^{-1} \cdot \mathrm{m}^{-1}$. The acid number is $198.5 \mathrm{mg}$ $\mathrm{KOH} / \mathrm{g} . \mathrm{IR} \mathrm{cm}^{-1}$ : $3010 v(\mathrm{O}-\mathrm{H}), 2922$ and $2852 v(\mathrm{C}-\mathrm{H}), 1737 v(\mathrm{O}-\mathrm{C}=\mathrm{O}), 1552 \delta(\mathrm{N}-\mathrm{H}), 1462$ and $1377 \delta(\mathrm{C}-\mathrm{H}), 1083 v(\mathrm{P}-\mathrm{O}), 721\left(\mathrm{CH}_{2}\right)_{\mathrm{x}}$. 
Surface-active properties of diethylolamide based on fish oil as well as its phosphate have been studied at the kerosene-water interface at $21^{\circ} \mathrm{C}$ using stalagmometric method.

The obtained products demonstrate high surface activity at the water-kerosene interface (Figure 1). Diethylolamide and TEA ester lower the interface tension from 5.0 down to 1.5 $\mathrm{mN} / \mathrm{m}$. At $1.0 \%$ concentration both diethylolamide and its phosphate have a high surface activity at the water-kerosene interface, reducing the surface tension from $46.5 \mathrm{mN} / \mathrm{m}$ down to 0.4 and $1.5 \mathrm{mN} / \mathrm{m}$, respectively. As this range of concentrations the tendency of phosphate derivatives for micelle formation is weak. So, determination of main colloidal-chemical parameters is difficult.

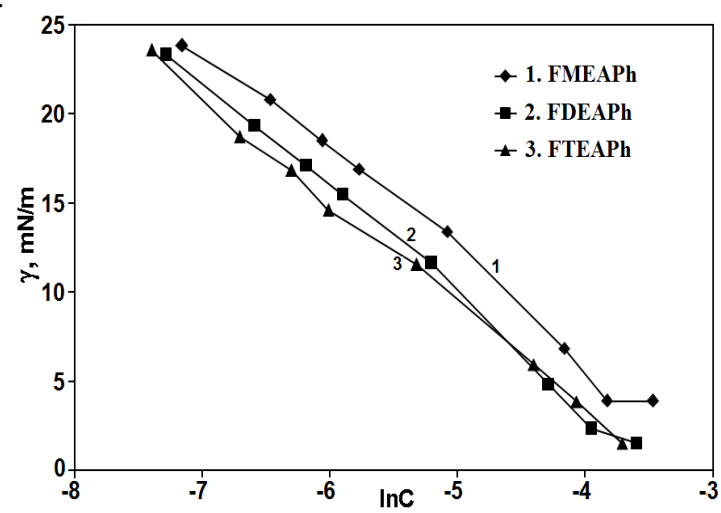

Figure 1. Interfacial tension vs. In of the concentration of various ethylolamides and TEA ester phosphates of fish oil in kerosene solution.

Petroleum-collecting and dispersing capacities of the phosphates have been studied in various waters (distilled, fresh and sea) using Ramana crude oil. These chemicals display effective collecting-dispersing properties in distilled and fresh waters. FDEAPh has a maximum collection coefficient 53.8 in distilled and 15.2 in fresh water. In the sea water this phosphate shows a high petroleum-dispersing capacity. For the all three phosphates the maximum time of action is $198 \mathrm{~h}$.

Petroleum-collecting and dispersing properties of FMEAPh, FDEAPh and FTEAPh in distilled, fresh and sea waters have also been studied using $2 \mathrm{~mL}$ of Ramany crude oil (thickness of the film $\sim 0.330 \mathrm{~mm}$ ) (Table 1). In distilled water FMEAPh, as $5 \%$ aqueous solution, has the value $\mathrm{K}_{\max }=10.1$ and $\tau_{\max }>6$ days. In the fresh water, for undiluted FMEAPh $\mathrm{K}_{\max }$ is 15.2 and $\tau_{\max }$ is 6 days. In the sea water, for both application forms of this chemical petroleum dispersing is observed. In the case of undiluted FDEAPh, in distilled water $\mathrm{K}_{\max }$ is 8.7, the duration of action exceeding 6 days. In fresh water this undiluted phosphate is a collector $\left(\mathrm{K}_{\max }=6.9, \tau_{\max }>\right.$ 3 days) whereas its $5 \%$ aqueous solution manifests mixed collecting-dispersing properties $\left(\mathrm{K}_{\max }\right.$ $=7.6 ; 89.7 \%$ of surface cleaning $\tau_{\max }>6$ days). In the sea water, both cases of this chemical application are characterized by mixed collecting-dispersing. The undiluted FDEAPh shows the values $\mathrm{K}_{\max }=7.2$, degree of surface cleaning $89.7 \%$ and $\tau_{\max }>6$ days. When FTEAPh is used in distilled and fresh waters, for both the undiluted and diluted forms of this ester petroleumcollecting is seen $\left(\mathrm{K}_{\max }=13.1\right.$ and $\tau_{\max }=6$ days $)$ while in the sea water the mixed effect (collecting-dispersing) is registered $\left(\mathrm{K}_{\max }=11.1, \tau_{\max }>3\right.$ days and degree of surface clean in $89.7 \%$ ). As is evident, at doubling the thickness of the slicks the efficiency is, in a whole, preserved. 
Table 1. Petroleum-collecting and petroleum-dispersing properties of fish oil ethylolamides and TEA ester phosphate derivatives; Ramana crude oil.

\begin{tabular}{|c|c|c|c|c|c|c|c|c|}
\hline \multirow[t]{2}{*}{ Reagent } & \multirow{2}{*}{$\begin{array}{c}\text { Surfactant } \\
\text { concentration }\end{array}$} & \multirow{2}{*}{$\begin{array}{c}\text { Oil slicks } \\
\text { thickness, } \\
\text { mm }\end{array}$} & \multicolumn{2}{|c|}{ Distilled water } & \multicolumn{2}{|c|}{ Fresh water } & \multicolumn{2}{|c|}{ Sea water } \\
\hline & & & Time, h & $\mathrm{K}$ & Time, $\mathrm{h}$ & $\mathrm{K}$ & Time, h & $\mathrm{K}$ \\
\hline \multirow[t]{4}{*}{ FMEAPh } & \multirow{2}{*}{$\begin{array}{l}\text { Undiluted } \\
\text { product }\end{array}$} & 0.165 & $0-198.0$ & Disp. & $0-198.0$ & Disp. & $0-198.0$ & Disp. \\
\hline & & 0.330 & $\begin{array}{c}0 \\
2.5-144.0\end{array}$ & $\begin{array}{l}3.4 \\
8.7\end{array}$ & $\begin{array}{c}0-3.0 \\
4.5-120.0 \\
144.0\end{array}$ & $\begin{array}{c}\text { Disp. } \\
15.9 \\
3.6 \\
\end{array}$ & $0-58.0$ & Disp. \\
\hline & \multirow{2}{*}{$\begin{array}{l}5 \% \text { wt. } \\
\text { aqueous } \\
\text { solution }\end{array}$} & 0.165 & $0-198.0$ & 13.5 & $0-198.0$ & Disp. & $0-198.0$ & Disp. \\
\hline & & 0.330 & $\begin{array}{c}0-2.5 \\
18.5-144.0\end{array}$ & $\begin{array}{c}4.5 \\
10.1\end{array}$ & $\begin{array}{c}0-26.5 \\
30.5-74.5 \\
124.5\end{array}$ & $\begin{array}{c}\text { Disp. } \\
7.6 \\
5.1 \\
\end{array}$ & $0-57.5$ & Disp. \\
\hline \multirow[t]{4}{*}{ FDEAPh } & \multirow{2}{*}{$\begin{array}{l}\text { Undiluted } \\
\text { product }\end{array}$} & 0.165 & $0-198.0$ & 53.8 & $102.0-198.0$ & 15.9 & $0-198.0$ & Disp. \\
\hline & & 0.330 & $\begin{array}{c}0-3.0 \\
22.5-144.5\end{array}$ & $\begin{array}{l}4.4 \\
8.7\end{array}$ & $\begin{array}{l}0-3.0 \\
144.5\end{array}$ & $\begin{array}{l}5.9 \\
4.7\end{array}$ & $\begin{array}{c}0-3.0 \\
22.5-74.5\end{array}$ & $\begin{array}{c}\text { Disp. } \\
7.2\end{array}$ \\
\hline & \multirow{2}{*}{$\begin{array}{l}5 \% \text { wt. } \\
\text { aqueous } \\
\text { solution }\end{array}$} & 0.165 & $\begin{array}{c}0-8.0 \\
30.0 \\
\end{array}$ & $\begin{array}{c}6.8 \\
\text { Disp. }\end{array}$ & $0-198.0$ & 6.7 & $\begin{array}{c}0 \\
8.0 \\
\end{array}$ & $\begin{array}{c}3.4 \\
\text { Disp. }\end{array}$ \\
\hline & & 0.330 & $\begin{array}{c}0-3.0 \\
22.5-74.5\end{array}$ & $\begin{array}{l}4.4 \\
8.1\end{array}$ & $\begin{array}{c}0-3.0 \\
18.5-144.5\end{array}$ & $\begin{array}{c}\text { Disp. } \\
7.6\end{array}$ & $\begin{array}{c}0-3.0 \\
18.5-72.5\end{array}$ & $\begin{array}{c}\text { Disp. } \\
3.5\end{array}$ \\
\hline \multirow[t]{4}{*}{ FTEAPh } & \multirow[t]{2}{*}{$\begin{array}{l}\text { Undiluted } \\
\text { product }\end{array}$} & 0.165 & $\begin{array}{c}0-8.0 \\
30.0 \\
198.0\end{array}$ & $\begin{array}{l}6.8 \\
9.9 \\
7.6 \\
\end{array}$ & $0-102.0$ & Disp. & $\begin{array}{c}0 \\
8.0-198.0\end{array}$ & $\begin{array}{c}8.7 \\
\text { Disp. }\end{array}$ \\
\hline & & 0.330 & $\begin{array}{c}0-3.0 \\
24.5-74.5 \\
\end{array}$ & $\begin{array}{l}4.7 \\
9.9 \\
\end{array}$ & $0-74.5$ & Disp. & $0-74.0$ & Disp. \\
\hline & \multirow{2}{*}{$\begin{array}{l}5 \% \text { wt. } \\
\text { aqueous } \\
\text { solution }\end{array}$} & 0.165 & $0-102.0$ & Disp. & $\begin{array}{c}0 \\
8.0-78.0 \\
\end{array}$ & $\begin{array}{c}5.5 \\
\text { Disp. }\end{array}$ & $\begin{array}{c}0 \\
8.0-102.0 \\
\end{array}$ & $\begin{array}{l}6.8 \\
4.4 \\
\end{array}$ \\
\hline & & 0.330 & $\begin{array}{c}0-3.0 \\
24.5-144.0\end{array}$ & $\begin{array}{c}7.5 \\
13.1 \\
\end{array}$ & $\begin{array}{c}0-3.0 \\
24.5-144.0\end{array}$ & $\begin{array}{c}8.7 \\
12.6\end{array}$ & $\begin{array}{c}0-3.0 \\
24.5-74.5\end{array}$ & $\begin{array}{l}11.1 \\
\text { Disp. }\end{array}$ \\
\hline
\end{tabular}

Petroleum-collecting and dispersing properties of FMEAPh were also studied with regard to three other types of crude oil (from May 28, Dubandy and Neft Dashlary oil fields). The registered results are given in Table 2 .

From this table it is seen that FMEAPh (undiluted and diluted) is a good collector for May 28 crude oil on the surface of all 4 waters. In distilled water $\mathrm{K}_{\max }$ reaches 60.8 and the time of action approaches 10 days (in the case of $5 \%$ water solution). In fresh and sea waters $\mathrm{K}_{\max }$ is 40.5, the duration of effectiveness reaching almost 10 days when the chemical is undiluted. In the layer water the value of $\mathrm{K}_{\max }$ is also high (40.5 for the diluted FMEAPh), the action being preserved during nearly 10 days.

As is evident from the table, the undiluted FMEAPh demonstrates good collecting properties in fresh water $\left(\mathrm{K}_{\max }=40.5, \tau_{\max }\right.$ reaching $\sim 10$ days $)$, a dispersing capacity in the sea water $\left(\tau_{\max } \sim\right.$ 10 days $)$ and a mixed activity in distilled and layer waters $\left(K_{\max }=30.3, \tau_{\max } \sim 10\right.$ days $)$. When this chemical is applied in the diluted form, dispersing is observed in the sea and layer waters and collecting-dispersing is registered in two soft waters $\left(\mathrm{K}_{\max }=15.2\right.$ and $\tau_{\max } \sim 10$ days $)$.

In the case of Dubandy crude oil the 5\% aqueous solution of FMEAPh displays a mixed action in the medium of all 4 waters $\left(\mathrm{K}_{\max }=20.3\right.$ and $\tau_{\max } \sim 10$ days in the sea water). The undiluted chemical possesses an effective collecting action in fresh and sea water surfaces $\left(\mathrm{K}_{\max }\right.$ $=30.4$ and $\tau_{\max } \sim 10$ days) whereas in distilled and layer waters a dual action is effected $\left(\mathrm{K}_{\mathrm{мах}}=\right.$ 24.5 and $\tau_{\max }$ nearing 10 days). The described reagents are not toxic because of harmlessness of fish oil and phosphate group which is vitally important for living organisms. Ethylolamide 
group is not hazardous either.

Table 2. Petroleum-collecting and petroleum-dispersing properties of fish oil FMEAPh regarding various crude oils.

\begin{tabular}{|c|c|c|c|c|c|c|c|c|c|}
\hline \multirow[t]{2}{*}{ Petroleum } & \multirow[t]{2}{*}{$\begin{array}{c}\text { Surfactant } \\
\text { concentration }\end{array}$} & \multicolumn{2}{|c|}{ Distilled water } & \multicolumn{2}{|c|}{ Fresh water } & \multicolumn{2}{|c|}{ Sea water } & \multicolumn{2}{|c|}{$\begin{array}{c}\text { Surakhany layer } \\
\text { water }\end{array}$} \\
\hline & & Time, $\mathrm{h}$ & $\mathrm{K}$ & Time, $\mathrm{h}$ & $\mathrm{K}$ & Time, $\mathrm{h}$ & $\mathrm{K}$ & Time, $\mathrm{h}$ & $\mathrm{K}$ \\
\hline \multirow{11}{*}{$\begin{array}{l}\text { May } 28 \text { oil } \\
\text { field }\end{array}$} & Undiluted & 0 & 24.3 & $0-35.0$ & Disp. & $0-62.0$ & 40.5 & $0-38.0$ & 30.4 \\
\hline & product & $1.5-2.0$ & 23.9 & $38.0-62.0$ & 39.5 & $68.0-92.0$ & 30.4 & 62.0 & 24.3 \\
\hline & & $32.0-35.0$ & 30.4 & 68.0 & 40.5 & $214.0-217.0$ & 24.5 & $68.0-214.0$ & Disp. \\
\hline & & 38.0 & 39.5 & $92.0-214.0$ & 30.4 & 231.0 & 17.4 & $217.0-231.0$ & 20.3 \\
\hline & & $62.0-92.0$ & 30.4 & $217.0-231.0$ & 40.5 & & & & \\
\hline & & $214.0-217.0$ & 19.4 & & & & & & \\
\hline & & 231.0 & 15.2 & & & & & & \\
\hline & $5 \%$ wt. & $0-32.0$ & 40.5 & $0-217.0$ & 20.3 & $0-217.0$ & 30.4 & $0-217.0$ & 40.5 \\
\hline & aqueous & $35.0-38.0$ & 60.8 & 231.0 & 10.1 & 231.0 & 15.2 & 231.0 & 15.2 \\
\hline & solution & $62.0-217.0$ & 40.5 & & & & & & \\
\hline & & 231.0 & 4.1 & & & & & & \\
\hline \multirow{7}{*}{$\begin{array}{c}\text { Neft } \\
\text { Dashlary oil } \\
\text { field }\end{array}$} & Undiluted & $0-32.0$ & Disp. & $0-92.0$ & 15.2 & $0-231.0$ & Disp. & $0-68.0$ & 20.3 \\
\hline & product & $35.0-92.0$ & 20.3 & 214.0 & 20.3 & & & $92.0-231.0$ & Disp. \\
\hline & & 214.0 & 30.3 & 217.0 & 17.4 & & & & \\
\hline & & 217.0 & 24.3 & 231.0 & 6.8 & & & & \\
\hline & & 231.0 & 15.2 & & & & & & \\
\hline & $5 \%$ wt. & 0 & 15.20 & 0 & 15.2 & $0-231.0$ & Disp. & $0-231.0$ & Disp. \\
\hline & $\begin{array}{l}\text { aqueous } \\
\text { solution }\end{array}$ & $1.5-231.0$ & Disp. & $1.5-231.0$ & Disp. & & & & \\
\hline \multirow{8}{*}{$\begin{array}{c}\text { Dubendy oil } \\
\text { terminal }\end{array}$} & Undiluted & 0 & 11.0 & $0-214.0$ & 30.4 & $0-32.0$ & 17.4 & $0-38.0$ & 20.3 \\
\hline & product & 1.5 & 13.6 & $217.0-231.0$ & 12.2 & $35.0-217.0$ & 15.2 & $62.0-231.0$ & Disp. \\
\hline & & 2.0 & 17.4 & & & 231.0 & 30.4 & & \\
\hline & & $32.0-35.0$ & 24.3 & & & & & & \\
\hline & & 38.0 & 15.2 & & & & & & \\
\hline & & $62.0-231.0$ & Disp. & & & & & & \\
\hline & $5 \%$ wt. & 0 & 30.4 & $0-32.0$ & 15.2 & 0 & 20.3 & 0 & 17.4 \\
\hline & $\begin{array}{l}\text { aqueous } \\
\text { solution }\end{array}$ & $1.5-231.0$ & Disp. & $35.0-231.0$ & Disp. & $1.5-231.0$ & Disp. & $1.5-231.0$ & Dis \\
\hline
\end{tabular}

Petroleum-collecting and petroleum dispersing capacities of FDEAPh have been studied on the surface of the distilled water in the presence of various inorganic salts (Table 3).

Petroleum-collecting capacity of diethylolamide phosphate has been studied on the example of solutions of the salts containing ions dominant in the sea water as well as layer water. As such inorganic salts, $\mathrm{NaCl}, \mathrm{MgSO}_{4} \cdot \mathrm{H}_{2} \mathrm{O}, \mathrm{CaCl}_{2} \cdot \mathrm{H}_{2} \mathrm{O}, \mathrm{NaHCO}_{3}, \mathrm{~K}_{2} \mathrm{CO}_{3}, \mathrm{KI}$ and $\mathrm{KBr}$ were taken. For preparation of these solutions the distilled water was used. Concentration of each salt (separately) in the distilled water approximately corresponds to the (total) amount of this salt in the sea water. Thus, concentration of $\mathrm{NaCl}$ in the distilled water equaled $6840 \mathrm{ppm}, \mathrm{MgSO}_{4}-$ 4514 ppm, $\mathrm{CaCl}_{2}-693$ ppm, $\mathrm{NaHCO}_{3}-230$ ppm, $\mathrm{K}_{2} \mathrm{CO}_{3}-124$ ppm, $\mathrm{KI}-72 \mathrm{ppm}$ and $\mathrm{KBr}-$ $28 \mathrm{ppm}$.

Phosphate derivative as an undiluted product displays petroleum-collecting effect in the saltless water during 8 days with maximum value of $\mathrm{K}=21.8$. In the presence of such salts as $\mathrm{NaCl}, \mathrm{KI}, \mathrm{KBr}$ and $\mathrm{MgSO}_{4}$ the magnitude of coefficient petroleum-collecting increases. The values of $\mathrm{K}_{\max }$ are 30.2, 42.8, 42.8 and 29.7, respectively, whereas the duration of activity exceed correspondingly $12,9,9$ and 9 days. In the case of $\mathrm{K}_{2} \mathrm{CO}_{3}$ and $\mathrm{NaHCO}_{3}$ petroleumcollecting capability is replaced by petroleum dispersing. 
Table 3. Petroleum-collecting and petroleum-dispersing properties of FDEAPh at various concentrations of salts.

\begin{tabular}{|c|c|c|c|c|c|}
\hline \multirow{2}{*}{ Salts } & \multirow{2}{*}{$\begin{array}{l}\text { Concentration, } \\
\text { ppm }\end{array}$} & \multicolumn{2}{|c|}{ Undiluted product } & \multicolumn{2}{|c|}{$5 \%$ wt. aqueous solution } \\
\hline & & $\tau_{\max }$, day & $\mathrm{K}_{\max }$ & $\tau_{\max }$, day & $\mathrm{K}_{\max }$ \\
\hline Without salts & - & 8 & 21.8 & 10 & 30.2 \\
\hline $\mathrm{NaCl}$ & $\begin{array}{l}6840 \times 1 \\
6840 \times 2 \\
6840 \times 3 \\
6840 \times 4 \\
6840 \times 5\end{array}$ & $\begin{array}{c}12 \\
5 \\
4 \\
3 \\
4\end{array}$ & $\begin{array}{l}30.2 \\
33.4 \\
18.8 \\
21.5 \\
24.0\end{array}$ & $\begin{array}{l}2 \\
6 \\
1 \\
1 \\
4\end{array}$ & $\begin{array}{c}29.7 \\
42.8 \\
\text { Disp. } \\
\text { Disp. } \\
24.0\end{array}$ \\
\hline $\mathrm{MgSO}_{4}$ & $\begin{array}{l}4514 \times 1 \\
4514 \times 2 \\
4514 \times 3 \\
4514 \times 4 \\
4514 \times 5 \\
\end{array}$ & $\begin{array}{l}9 \\
6 \\
3 \\
4 \\
4\end{array}$ & $\begin{array}{l}29.7 \\
18.8 \\
18.8 \\
33.4 \\
18.8\end{array}$ & $\begin{array}{c}2 \\
6 \\
3 \\
0.5 \\
4\end{array}$ & $\begin{array}{l}29.7 \\
18.8 \\
21.5 \\
21.5 \\
18.8\end{array}$ \\
\hline $\mathrm{CaCl}_{2}$ & $\begin{array}{l}693 \times 1 \\
693 \times 2 \\
693 \times 3 \\
693 \times 4 \\
693 \times 5\end{array}$ & $\begin{array}{l}2 \\
6 \\
2 \\
4 \\
4\end{array}$ & $\begin{array}{c}\text { Disp. } \\
15.4 \\
\text { Disp. } \\
37.7 \\
15.4\end{array}$ & $\begin{array}{c}0.5 \\
0.5 \\
2 \\
4 \\
4\end{array}$ & $\begin{array}{l}19.9 \\
18.8 \\
\text { Disp. } \\
\text { Disp. } \\
\text { Disp. }\end{array}$ \\
\hline $\mathrm{NaHCO}_{3}$ & $\begin{array}{l}230 \times 1 \\
230 \times 2 \\
230 \times 3 \\
230 \times 4 \\
230 \times 5\end{array}$ & $\begin{array}{l}3 \\
5 \\
7 \\
4 \\
3\end{array}$ & $\begin{array}{l}\text { Disp. } \\
\text { Disp. } \\
\text { Disp. } \\
\text { Disp. } \\
\text { Disp. }\end{array}$ & $\begin{array}{l}3 \\
6 \\
1 \\
4 \\
3\end{array}$ & $\begin{array}{l}\text { Disp. } \\
\text { Disp. } \\
\text { Disp. } \\
\text { Disp. } \\
\text { Disp. }\end{array}$ \\
\hline $\mathrm{K}_{2} \mathrm{CO}_{3}$ & $\begin{array}{l}124 \times 1 \\
124 \times 2 \\
124 \times 3 \\
124 \times 4 \\
124 \times 5\end{array}$ & $\begin{array}{l}7 \\
4 \\
4 \\
4 \\
4\end{array}$ & $\begin{array}{l}\text { Disp. } \\
\text { Disp. } \\
\text { Disp. } \\
\text { Disp. } \\
\text { Disp. }\end{array}$ & $\begin{array}{l}2 \\
4 \\
4 \\
2 \\
1\end{array}$ & $\begin{array}{c}15.1 \\
12.6 \\
\text { Disp. } \\
16.8 \\
12.6\end{array}$ \\
\hline KI & $\begin{array}{l}72 \times 1 \\
72 \times 2 \\
72 \times 3 \\
72 \times 4 \\
72 \times 5\end{array}$ & $\begin{array}{l}9 \\
6 \\
1 \\
3 \\
4\end{array}$ & $\begin{array}{l}42.8 \\
16.7 \\
25.1 \\
33.4 \\
42.8\end{array}$ & $\begin{array}{c}2 \\
2 \\
4 \\
0.5 \\
1\end{array}$ & $\begin{array}{l}19.9 \\
18.8 \\
12.6 \\
18.8 \\
18.8\end{array}$ \\
\hline $\mathrm{KBr}$ & $\begin{array}{l}28 \times 1 \\
28 \times 2 \\
28 \times 3 \\
28 \times 4 \\
28 \times 5\end{array}$ & $\begin{array}{l}9 \\
6 \\
3 \\
4 \\
4\end{array}$ & $\begin{array}{l}42.8 \\
33.4 \\
16.8 \\
33.4 \\
42.8\end{array}$ & $\begin{array}{l}3 \\
6 \\
3 \\
4 \\
1\end{array}$ & $\begin{array}{c}15.4 \\
33.4 \\
\text { Disp. } \\
24.0 \\
18.8\end{array}$ \\
\hline
\end{tabular}

As is seen, such salts as $\mathrm{NaCl}, \mathrm{MgSO}_{4}, \mathrm{KBr}$ and $\mathrm{KI}$ in water contribute to an increase of petroleum-collecting efficiency. Such salts as $\mathrm{CaCl}_{2}, \mathrm{~K}_{2} \mathrm{CO}_{3}$ and $\mathrm{NaHCO}_{3}$ when being present in water cause petroleum dispersing. Therefore, it may be concluded that $\mathrm{Na}^{+}, \mathrm{K}^{+}, \mathrm{Mg}^{2+}$ cations and $\mathrm{Cl}^{-}, \mathrm{Br}^{-}, \mathrm{I}^{-}, \mathrm{SO}_{4}{ }^{2-}$ anions favor petroleum collecting whereas with $\mathrm{Ca}^{2+}$ cation as well as $\mathrm{HCO}_{3}{ }^{-}$and $\mathrm{CO}_{3}{ }^{2-}$ anions dispersing is observed.

With $5 \%$ wt. aqueous solution of phosphate in distilled water $\mathrm{K}_{\max }$ and $\tau_{\max }$ are respectively 30.2 and 10 days. In the presence of $\mathrm{NaCl}, \mathrm{MgSO}_{4}, \mathrm{CaCl}_{2}, \mathrm{~K}_{2} \mathrm{CO}_{3}, \mathrm{KBr}$ and $\mathrm{KI}$ the values of $\mathrm{K}_{\max }$ of $5 \%$ wt. aqueous solution of the phosphate equal 29.7, 29.7, 19.9, 15.1, 19.9 and 15.4, respectively, whereas durations of action are correspondingly $2,2,0.5,2,2$ and 3 days. In the 
case of $\mathrm{NaHCO}_{3}$ petroleum dispersing is observed. Comparison with the case without salts shows that in the presence of salts petroleum-collecting coefficient and duration of action decrease. Therefore, efficiency of the phosphate $5 \%$ solution is negatively impacted by the mineral salts present in water.

When concentration of the salts is doubled, with undiluted phosphate $\mathrm{K}_{\max }$ rises in the case of $\mathrm{NaCl}$ whereas with $\mathrm{MgSO}_{4}, \mathrm{KBr}$ and $\mathrm{KI}$ both $\mathrm{K}_{\max }$ and $\tau_{\max }$ decrease. Doubling the amount of $\mathrm{CaCl}_{2}$ leads to replacement of petroleum dispersing by collecting $\left(\mathrm{K}_{\max }=15.4, \tau_{\max }=6\right.$ days $)$.

When the amount of the salts is increased 3-5 times, in the cases of $\mathrm{NaCl}, \mathrm{KBr}$ and $\mathrm{KI}$ the petroleum-collection coefficient of the undiluted reagent mainly exceeds that for the medium of the distilled water (without salts). Duration of the reagent action is 3-4 days. With $\mathrm{MgSO}_{4}$ phosphate retains its activity, at 4-fold amount of this salt $\mathrm{K}_{\max }$ equaling 33.4. The 4-fold increase of $\mathrm{CaCl}_{2}$ concentration promotes an augmentation of the $\mathrm{K}_{\max }$. With the 3-5-fold excess amounts of $\mathrm{NaHCO}_{3}$ and $\mathrm{K}_{2} \mathrm{CO}_{3}$ dispersing of petroleum slick occurs like with the less quantities of these salts.

When the 5\% wt. phosphate aqueous solution is applied in the water containing 2-5-fold excess amounts of the salts, $\mathrm{K}_{\max }$ becomes higher than in the distilled water at the doubled quantities of $\mathrm{NaCl}$ (42.8) and $\mathrm{KBr}$ (33.4). In the other cases either $\mathrm{K}_{\max }$ becomes lower than in the distilled water or dispersing occurs.

\section{CONCLUSIONS}

The ethylolamides and TEA ester based on fish oil and ethanolamines (mono-, di- and triethanolamine) as well as their phosphates have been synthesized. Their high surface activity at the water-kerosene interface has been experimentally shown. Collecting and dispersing of thin petroleum slicks off the surface of the distilled, fresh, the Caspian Sea and layer waters under the influence of the synthesized chemicals have been revealed. According to the results of researches of the influence of various salts on petroleum-collecting capability of the undiluted phosphate, $\mathrm{Mg}^{2+}, \mathrm{Na}^{+}, \mathrm{K}^{+}$cations and $\mathrm{Cl}^{-}, \mathrm{Br}^{-}, \mathrm{I}^{-}$anions enhance this capacity while $\mathrm{HCO}_{3}^{-}$and $\mathrm{CO}_{3}{ }^{2-}$ anions cause petroleum-dispersing properties. When 5\% FDEAPh solution is used, mineral salts mainly decrease petroleum-collecting capacity.

\section{ACKNOWLEDGMENTS}

The authors would like to thank the Institute of Petrochemical Processes of National Academy of Sciences of Azerbaijan for the financial support.

\section{REFERENCES}

1. Abbasov, V.M. Processes of Petrochemisty and Oil Refining 2002, 4, 6.

2. Tolosa, I.; Mora, S.; Sheikholeslami, M.R.; Villeneuve, J.-P.; Bartocci, J.; Cattini, Ch. Marine Pollut. Bull. 2004, 48, 44.

3. Khatoonabadai, A.; Dehcheshmeh, A.R.M. Int. J. Environ. Pollut. 2006, 26, 347.

4. Clark, R.B.; Frid, Ch.; Attrill, M. Marine Pollution, Clarendon Press: Oxford; 1997.

5. Abbasova, A.; Bagirova, K.; Campbell, G.; Clark, J.; Gallagher, R.; Garajayeva, N.; GeorgeAres, A.; Huseynova, L.; Neilson, D.; Roddie, B.; Tait, R. International Oil Spill Conference, IOSC 2005, 247.

6. De Voss, E.A. US Patent 3968041, 1976.

7. Blondina, G.J.; Singer, M.M.; Lee, I.; Ouano, M.T.; Hodgins, M.; Tjeerdema, R.S.; Sowby, 
M.L. Spill Sci. Technol. Bull. 1999, 5, 127.

8. Robert, J.F.; Alun, L. Pure Appl. Chem. 1999, 71, 27.

9. Lepain, A.O. US Patent 4224152, 1980.

10. Canevari, G.P. Oil Spill Conference 1985, 441.

11. Fingas, M.E.; Kyle, D.A.; Holmes, J.B.; Tennyson, E.J. International Oil Spill Conference, IOSC 2005, 2273.

12. Sterling, C.; Bonner, J.; Ernest, A.; Page, C.; Autenrieth, R. Marine Pollut. Bull. 2004, 48, 969.

13. Moles, A.; Holland L.; Short, J. Spill Sci. Technol. Bull. 2002, 7, 241.

14. Byford, D.C.; Green, P.J.; Lewis, A. in Proceedings of the Sixth Arctic Marine Oil spill Program Technical Seminar 1983, 140.

15. Fingas, M.F.; Bier, I.; Bobra, M.; Callaghan, S. in International Oil Spill Conference IOSC, $1991,419$.

16. Asadov, Z.G.; Aga-zade, A.D.; Zarbalieva, I.A.; Akhmedova, G.A. Petroleum Refin. Petrochem. 2010, 2, 21 (in Russian).

17. Asadov, Z.H.; Ahmadova, G.A.; Rahimov, R.A. Materials Innovations Res. 2010, 14, 327.

18. Asadov, Z.H.; Salamova, N.V.; Ahmadova, G.A.; Aga-zade, A.D. Process Petrochem Oil Refin. 2008, 33, 19 (in Russian).

19. Asadov, Z.H.; Aga-zade, A.D.; Salamova, N.V.; Eyubova, S.K.; Ahmadova, G.A.; Mamedova, Kh.A. Georgia Chem. J. 2010, 10, 43 (in Russian). 